\title{
L'intubation trachéale hors du bloc opératoire
}

Pascal Labrecque MD

$\mathrm{P}$

ENDANT ma résidence en anesthésie durant la première moitié des années $80, j$ 'ai peu entendu parler d'intubation trachéale difficile. Ce n'était pas là un sujet qui semblait préoccuper outre mesure mes professeurs et plus généralement la communauté des anesthésiologistes. Je crois qu'on était généralement satisfait des outils et techniques disponibles et populaires à l'époque et des résultats qu'on arrivait à en tirer. Certains de mes patrons m'avaient même certifié n'avoir jamais manqué leur coup avec un laryngoscope...

Heureusement, en même temps, certains anesthésiologistes, malgré une habileté exceptionnelle (seulement 13 expositions de grade III et IV en 3800 laryngoscopies sur une période de sept ans pour C. Doré), arrivaient à analyser leurs échecs pour tenter d'en tirer des leçons et en faire profiter leurs pairs. ${ }^{1-3}$ Des rapports américains de réclamations inscrites aux noms des victimes d'accidents anesthésiques survenus lors de l'intubation trachéale et largement diffusés ${ }^{4}$ contribuèrent à approfondir la réflexion. Au Québec, le bureau du Coroner, enquêtant sur des décès survenus en salle d'opération, permit aux anesthésiologistes de mon entourage de prendre conscience, si ce n'était déjà fait, que ces catastrophes n'arrivaient pas seulement à l'étranger et que mieux valait s'en préoccuper.

Au tournant des années 90, le développement continu de l'anesthésie régionale et la disponibilité grandissante de nouveaux outils permettant l'accès au larynx, dont les endoscopes souples à fibres optiques, rendirent les anesthésiologistes plus à l'aise avec l'idée que l'on pouvait, en employant judicieusement les anesthésiques locaux, intuber la trachée de patients éveillés. Dans son article phare publié en 1991, Benumof faisait ainsi une large place à l'intubation trachéale de patients éveillés et aux nécessaires finesses qui la rendaient possible et relativement confortable. ${ }^{5}$

Lorsqu'on leur a présenté divers scénarios d'accès difficile prévu ou pressenti aux voies respiratoires, dans la plupart des cas, la majorité des anesthésiologistes américains questionnés en 1996 ont choisi une technique d'intubation vigile avec sédation plutôt que l'anesthésie générale en ventilation spontanée ou l'anesthésie générale avec apnée. Chez les anesthésiologistes moins âgés, cette tendance était encore plus marquée. 6 Dans une enquête canadienne plus récente, sauf dans les cas de traumatismes avec patient noncoopératif et d'hémorragie post-amygdalectomie, les anesthésiologistes canadiens ont aussi choisi, dans la plupart des cas d'accès difficile prévu, de garder le patient éveillé pour l'intubation trachéale. Encore une fois, les anesthésiologistes plus jeunes semblaient plus à l'aise avec une approche vigile. ${ }^{7}$ Ainsi, lorsqu'ils appréhendent des difficultés à l'intubation, se développe, chez les anesthésiologistes nord-américains, une tendance lourde à éviter d'induire l'inconscience et à fortiori l'apnée du patient avant que le tube trachéal ne soit en place.

Il devient donc important de savoir discerner à l'avance les difficultés susceptibles d'entraver l'intubation trachéale que l'on s'apprête à entreprendre. Malheureusement, même si elle est fortement recommandée, l'évaluation pré-anesthésique n'arrivera pas toujours à distinguer les écueils et on doit alors pouvoir facilement mettre en oeuvre une stratégie de rechange éprouvée et familière en cas d'échec initial. ${ }^{8}$

Bien qu'ils réalisent la plupart de leurs intubations trachéales lors de cas programmés et dans le confort de l'environnement protégé de leur bloc opératoire, les anesthésiologistes sont souvent appelés à intervenir chez des patients gravement malades, le plus souvent en détresse respiratoire, aux étages cliniques, aux soins intensifs, à l'unité coronarienne et plus rarement à l'urgence. Lorsqu'une intubation trachéale s'impose chez ces malades, l'évaluation préalable des voies respiratoires est souvent difficile à réaliser. Les patients en détresse n'ont plus aucune réserve physiologique et deviendraient rapidement très hypoxémiques si une

Du département d'anesthésie, Centre hospitalier universitaire de Québec, Québec, Québec, Canada.

Adresser la correspondance à: Dr Pascal Labrecque, Département d'anesthésie, Centre hospitalier universitaire de Québec, Pavillon l'Hôtel-Dieu de Québec, 11, Côte du Palais, Québec, Québec GlR 2J6, Canada. Téléphone: 418-691-5323; Télécopieur: 418-691-5097; Courriel: pascal.labrecque@videotron.ca 
éventuelle apnée devait se prolonger. L'aide technique nécessaire laisse parfois à désirer et l'équipement de secours n'est pas toujours disponible aussi facilement qu'au bloc opératoire. On ne doit donc pas se surprendre que l'incidence de difficulté à l'intubation soit beaucoup plus élevée en dehors du bloc opératoire. ${ }^{9}$

C'est pourquoi, lorsqu'ils ont à intuber un patient en détresse respiratoire en dehors du bloc opératoire, les anesthésiologistes canadiens tendent à adopter une approche extrêmement prudente en privilégiant, le plus souvent, une technique vigile. Dans la plupart des cas, il est possible de diminuer la détresse du patient et d'obtenir sa collaboration, en évitant le décubitus dorsal complet et en corrigeant partiellement l'hypoxémie et l'hypercapnie par la ventilation assistée en pression positive au masque. Il est aussi utile de lui expliquer sommairement et au fur et à mesure ce que nous sommes en train de faire. On peut aussi accessoirement titrer de mini doses d'opioïde à action rapide pour diminuer la dyspnée et/ou de midazolam pour contrôler l'anxiété, en faisant bien attention de ne pas perdre le contact avec le patient qui doit continuer à obéir aux ordres, quitte à utiliser des antagonistes au besoin. L'anesthésie locale des muqueuses par la lidocaïne atomisée doit se faire progressivement jusqu'à l'épiglotte, en alternance avec la ventilation au masque alors qu'à chaque fois, la lame du laryngoscope rigide avance un peu plus loin. En dernier lieu, de la lidocaïne à $4 \%$ peut-être injectée entre les cordes vocales, dans le larynx supérieur pour diminuer la toux lors du passage du tube trachéal. Le succès de cette technique requiert toutefois que l'on prenne son temps en se rappelant que l'action de l'anesthésique local n'est pas instantanée. Cette technique de laryngoscopie directe (et d'intubation trachéale dans mon cas), à défaut d'être confortable, est très bien tolérée tel qu'en fait foi l'expérience de nombreux anesthésiologistes volontaires qui se sont prêtés au jeu, de façon répétée, sans l'aide d'aucun sédatif. ${ }^{10}$ Elle exige toutefois de faire notre deuil de l'élégance apparente des "conditions optimales d'intubation" chérie par certains. Alors qu'on remédie à une grande détresse, que nous importe de toute façon qu'il y ait un haut-le-cœur transitoire et sans conséquence, que les cordes vocales bougent ou qu'il y ait un peu de toux ou de mouvement des membres lors du passage du tube dans la trachée?

Dans la revue de George Kovacs et coll. publié dans ce numéro du Journal, on peut prendre toute la mesure de la distance qui sépare l'attitude des anesthésiologistes canadiens de celle qui prévaut dans la littérature émanant des urgentologues quant à la gestion de l'intubation trachéale des patients de l'urgence. ${ }^{11}$
On y apprend que l'intubation (et non l'induction) en séquence rapide (ISR), où l'on anesthésie (avec agents hypnotiques et curares) le patient pour faciliter l'intubation trachéale est de plus en plus employée par les urgentologues. Utilisée parcimonieusement au début des années 80 dans les cas de patients obnubilés dont on ne pouvait ouvrir la bouche, la succinylcholine fait maintenant partie des mœurs à l'urgence et l'ISR y serait devenue la méthode «normale» d'intubation trachéale en l'absence de contre-indication. Heureusement, on apprend aussi à la lecture de ce travail que, selon les articles révisés (provenant surtout de centres tertiaires), le taux de succès de l'ISR à l'urgence est élevé et les complications moins fréquentes qu'avec les techniques qu'employaient auparavant les urgentologues, soit : la sédation sans curare, la technique sans médicament et l'intubation nasale à l'aveugle...

Les auteurs conviennent toutefois que les taux de complications de l'ISR telle qu'employée dans les urgences d'hôpitaux plus petits est inconnue. De plus, ils déplorent que la formation de certains médecins travaillant à l'urgence soit variable et parfois minimale quant aux techniques d'intubation trachéale et de gestion des voies respiratoires. C'est pour cette raison que les auteurs, urgentologues de profession, ont voulu publier leur article dans un journal d'anesthésie. Ils y font appel à nous, anesthésiologistes pour que nous participions de façon active à leur formation (initiale et continue) afin d'améliorer leur compétence dans la gestion des voies respiratoires.

Au delà de notre expertise, ils nous voient probablement comme ceux qui contrôlent l'accès à une cohorte de patients anesthésiés, élément incontournable pour mettre en pratique les notions théoriques acquises. $\mathrm{Si}$, dans ce que nous enseignons aux urgentologues, nous nous limitons à ce qui est trop souvent perçu par les étudiants en médecine comme " $\mathrm{La}$ Technique", soit l'intubation trachéale de patients inconscients et complètement immobiles parce que curarisés (pas si différents d'un mannequin après tout), nous ne devrons pas nous surprendre qu'ils cherchent ultérieurement à recréer à tout prix ces conditions. Nous devrons aussi, bien sûr, leur montrer à ventiler correctement au masque, technique essentielle mais difficile d'apprentissage de même qu'à utiliser les adjuvants et les solutions de rechange à la laryngoscopie directe en cas d'échec initial à l'intubation. Toutefois, ce que nous pourrons leur montrer de plus précieux, quant à moi, c'est ce que nous adopterions nous-mêmes si nous étions confrontés à nombre de leurs patients, soit l'approche à l'intubation trachéale vigile, similaire à celle qui est décrite plus haut. Malheureusement, les urgentologues et ceux qui 
aspirent à cette fonction ne pourront apprendre à faire des intubations vigiles en un mois de séjour en salle d'opération entre 8 h et 16 h en semaine. Ce type d'intervention non-programmable s'impose le plus souvent en dehors des heures ouvrables et les apprentis devront donc être disponibles pendant de longues périodes. De plus, afin de ne pas diluer l'exposition clinique et desservir nos propres résidents en anesthésie, il faudra nous restreindre à n'entraîner que ces médecins qui feront vraiment du travail à l'urgence une profession. Par ailleurs, les urgentologues pourraient profiter de nos rares disponibilités en nous invitant à l'urgence lorsqu'ils planifient une intubation trachéale ou s'exercer entre eux avec notre aide.

Une meilleure formation des urgentologues quant à la gestion des voies respiratoires réduira vraisemblablement les appels à l'aide qu'ils nous logent parfois en catastrophe pour des cas qui en fin de compte s'avèrent faciles selon nos standards. De plus, les complications survenant chez les patients de l'urgence pourraient se faire moins nombreuses. C'est à espérer parce qu'à défaut d'un registre complet des accidents survenant lors de l'intubation, les archives du Bureau du coroner du Québec nous avaient déjà révélé que de 1986 à 1993, trois décès étaient survenus en salle d'opération lors de tentatives d'intubation infructueuses où l'anesthésiologiste avait induit une apnée médicamenteuse. Depuis, en anesthésie, aucun problème de cette nature n'a fait l'objet d'une enquête du coroner dans cette province. Toutefois, un examen récent de ces mêmes archives indique que de 1996 à 2002, c'est à l'urgence que sont survenus trois décès similaires. Espérons que ce n'est là que le fruit d'un cruel hasard et que les anesthésiologistes et les urgentologues qui, sur la même route, semblent avoir emprunté des directions opposées, sauront retrouver des cours plus parallèles.

\section{Tracheal intubation} outside of the operating room

During my training in anesthesia, in the first half of the 1980's, I did not hear much about difficult tracheal intubation. My teachers were not overly concerned by the topic and neither was the larger community of practicing anesthesiologists. It seems that we were generally happy with the tools and techniques available and popular at the time and the results we achieved with them. Some of the staff anesthesiologists I worked with had even assured me that they had never missed with a rigid laryngoscope...

Hopefully, during the same period and sometime despite exceptional skills (only 13 grade III and IV laryngoscopic views in 3,800 laryngoscopies over seven years for C. Doré), other concerned individuals managed to analyze their own failures to draw lessons we could all benefit from. ${ }^{1-3}$ Eventually, the analysis of closed claims which had been filed on behalf of American patients who had suffered an adverse respiratory event during tracheal intubation was largely circulated and contributed a lot to the evolution of thought. ${ }^{4}$ In Quebec, the Coroner's office, with its inquiries into deaths which had occurred in the operating room (OR), served as an eye opener for those anesthesiologists of my immediate community, making us realize that such catastrophes did not only happen abroad and that we too should better feel concerned about them.

At the turn of the 1990's, the ongoing development of regional anesthesia and the increasing availability of new tools permitting access to the larynx, including flexible fibreoptic endoscopes, contributed to the wider acceptation by anesthesiologists of the idea that with the judicious use of local anesthetics, one could intubate the trachea of awake patients. In his 1991 landmark article, Benumof discussed at length the topic of awake tracheal intubation and the necessary tips which made it possible and relatively comfortable. ${ }^{5}$

When presented with different clinical scenarios of known or suspected difficult airway, the majority of American anesthesiologists polled in 1996 chose, in most cases, an awake tracheal intubation with sedation approach over intubation under general anesthesia with spontaneous ventilation preserved or with apnea. This inclination in favour of awake intubation was more pronounced amongst the younger anesthesiologists. ${ }^{6}$ In a more recent Canadian study of similar design, again for most scenarios of predicted difficult airway (with the exception of uncooperative trauma patient and post-tonsillectomy hemorrhage), Canadian anesthesiologists chose to keep the patient awake for tracheal intubation. Again, the younger anesthesiologist seemed to be more comfortable with an awake approach. ${ }^{7}$ So, it is quite clear that when a difficult intubation is suspected, North American anesthesiologists increasingly try to avoid the induction of unconsciousness and moreover that of apnea before the proper positioning of the tracheal tube.

Therefore, it would be important to detect in advance those features which might interfere with the 
tracheal intubation one is about to undertake. Unfortunately, even if it is highly recommended, the preanesthetic evaluation will not always pick-up all the obstacles and, should a first attempt at intubation fail, one should be able to easily and successfully use an alternative strategy one is familiar with. ${ }^{8}$

Even if they perform most of their tracheal intubations during elective cases in the comfort of the OR protected environment, anesthesiologists are often called upon to help with severely sick patients, usually in respiratory failure, on the wards, in the intensive care and coronary care units and sometimes, in the emergency room (ER). When those patients need to have their trachea intubated, a prior thorough evaluation of the airway is often difficult to perform. Such patients have no physiological reserve and would rapidly become severely hypoxemic should an eventual apnea be prolonged. In addition, in those environments, the necessary technical help may not be optimal and rescue equipment is not always as available as in the OR. Therefore, it is no surprise that the incidence of difficult intubation is much higher outside of the OR. ${ }^{9}$

That is why, when they have to intubate a patient in distress outside of the OR, Canadian anesthesiologists tend to adopt an extremely prudent approach, using, most of the time, an awake technique. In most cases, it is possible to decrease the patient's distress and even make him co-operate with the process, by maintaining a semi-sitting position while partially correcting his hypoxemia and hypercapnia by gentle bag and mask assisted ventilation. Providing the patient with brief explanations of what one is doing, along the way, also helps. Titration of very low doses of short acting opioids to decrease dyspnea and midazolam to control anxiety is optional and one must be careful not to lose contact with the patient who has to continue to obey commands, using antagonist agents if needed. Topical anesthesia of the airway mucosa with lidocaine spray should be done slowly and progressively, all the way down to the epiglottis, interrupted by bag and mask ventilation as, each time, the blade of the rigid laryngoscope advances a little further. As a last step, $4 \%$ lidocaine can be injected through the vocal cords, in the superior larynx, to decrease the cough associated with the insertion of the tracheal tube. The success of this technique requires that the operator take his time, remembering that the action of local anesthetics is not instantaneous. Such a direct laryngoscopy technique (including tracheal intubation in my case), short of being comfortable, is very well tolerated as related by the numerous anesthesiologists who repeatedly subjected themselves to the exercise as volunteers, without the help of any sedation. ${ }^{10}$ Of course, one must put aside the quest for the elegance of the "optimal intubation conditions". But when remedying to a great distress, should we be bothered by a benign and transient retch, by moving vocal cords and by a little cough or limb movement as the tube enters the trachea?

While reading the review article by Kovacs et al. published in this issue of the Journal, one can grasp the distance that exists between the opinion of Canadian anesthesiologists and that which prevails in the emergency medicine literature concerning the tracheal intubation of patients in the ER. ${ }^{11}$ The authors tell us that rapid sequence intubation, [(RSI), not induction] where the patient is anesthetized (with hypnotic agents and muscle relaxants) to facilitate tracheal intubation, is employed more and more by ER physicians. Used sparingly in the ER in the early 80's for cases of obtunded patients who required intubation but would not open their mouth, succinylcholine is now in common use and, in the ER, RSI has become the "norm" for intubating the patient's trachea in the absence of contraindication. It is also interesting to read that, according to the articles revised (mostly issued from tertiary care centres), the success rate of RSI in the ER is higher and complications less common than with the techniques used in the past by ER physicians such as: sedation without muscle relaxants, a technique without drugs and, blind nasal intubation...

The authors do admit though that the complication rate of RSI as practiced in the real life of smaller hospital ERs is unknown. In addition, they also recognize that, concerning tracheal intubation and airway management, the training of some physicians working in the ER can be variable and sometimes minimal. That is the very reason why the authors, ER physicians themselves, wanted their work published in an anesthesia journal. They are calling upon us, anesthesiologists, to actively participate in their education (initial and continuing) such as to improve their competency in airway management.

Beyond our expertise, they probably see us as controlling the access to cohorts of anesthetized patients, a fundamental element if one is to put into practice the theoretical notions acquired. If we were to limit ourselves in our teaching directed at ER physicians, to what is too often considered by medical students as "The Technique": tracheal intubation of unconscious and totally immobile paralyzed patients (not that different from a mannequin after all), we should not be surprised if, later on, they tried to reproduce those conditions at all cost. Of course, we will have to teach them correct bag and mask ventilation, a technique as essential as difficult to learn, and also to use adjuncts 
and alternatives to direct laryngoscopy should an initial attempt at intubation fail. But to me, the most important thing we should be able to teach ER physicians, is what we would often use ourselves if we had to deal with many of their patients, an awake intubation approach, similar to the one described above. Unfortunately, there is no way that ER physicians and trainees in ER medicine will learn how to properly do awake intubations in a month long rotation in the OR between 8:00 and 16:00 on week days. This type of intervention can hardly be planned and most of the time will have to be performed outside of regular hours and trainees will therefore need to be extremely available. Furthermore, to avoid dilution of the necessary clinical exposure our own residents deserve, we will have to limit this, out of hours training in airway management, to those physicians who will make working in the ER, a profession. In addition, ER physicians could take advantage of our rare moments of availability by inviting us to the ER when they are planning a tracheal intubation; they could also practice between themselves with our help.

Better training in airway management of ER physicians will likely reduce the number of times they call us for help in a crisis, for cases which ultimately are judged to be "easy" by our standards. Moreover, complications of airway management initiated in the ER would occur less often. Let us hope so because, short of a comprehensive registry of accidents with tracheal intubation, files from the Quebec Coroner's office yielded three cases of death which had occurred in ORs after the induction of apnea followed by failed intubation between 1986 and 1993. Since then, in anesthesia, no such case has been the object of a coroner's inquiry in this province. However, I recently reviewed the coroner's files and found that between 1996 to 2002, three similar deaths occurred, not in ORs, but in ERs. Maybe this apparent shift in the site of lethal airway complications was caused by chance alone but I still hope that anesthesiologists and ER physicians who, in airway management, seem to be going in opposite directions, will reconcile their diverging views.

\section{Références}

1 Mallampati SR, Gatt SP, Gugino LD, et al. A clinical sign to predict difficult tracheal intubation: a prospective study. Can Anaesth Soc J 1985; 32: 429-34.

2 Samsoon GL, Young JR. Difficult tracheal intubation: a retrospective study. Anaesthesia 1987; 42: 487-90.

3 Bellhouse CP, Dore C. Criteria for estimating likelihood of difficulty of endotracheal intubation with Macintosh laryngoscope. Anesth Intensive Care 1988; 16: 329-37.
4 Caplan RA, Posner KL, Ward RJ, Cheney FW. Adverse respiratory events in anesthesia: a closed claims analysis. Anesthesiology 1990; 72: 828-33.

5 Benumof JL. Management of the difficult adult airway. With special emphasis on awake tracheal intubation. Anesthesiology 1991; 75: 1087-110.

6 Rosenblatt WH, Wagner PJ, Ovassapian A, Kain ZN. Practice patterns in managing the difficult airway by anesthesiologists in the United States. Anesth Analg 1998; 87: 153-7.

7 Jenkins K, Wong DT, Correa R. Management choices for the difficult airway by anesthesiologists in Canada. Can J Anesth 2002; 49: 850-6.

8 Crosby ET, Cooper RM, Douglas MJ, et al. The unanticipated difficult airway with recommendations for management. Can J Anaesth 1998; 45: 757-76.

9 Schwartz DE, Matthay MA, Cohen NH. Death and other complications of emergency airway management in critically ill adults. A prospective investigation of 297 tracheal intubations. Anesthesiology 1995; 82: 367-76.

10 Sitzman BT, Rich GF, Rockwell JJ, Leisure GS, Durieux $M E$, DiFazio CA. Local anesthetic administration for awake direct laryngoscopy. Are glossopharyngeal nerve blocks superior? Anesthesiology 1997; 86: 34-40.

11 Kovacs G, Law JA, Ross J, et al. Acute airway management in the emergency department by non-anesthesiologists. Can J Anesth 2004; 51: 174-80. 